\title{
MENSWAARDIGHEID NA TIEN JAAR VAN REGSTAATLIKHEID IN SUID-
}

\section{AFRIKA $^{1}$}

\section{'n Toespraak ter inleiding van die tema: Die verwesenliking van menswaardigheid in die huidige tydsgewrig}

\author{
LWH Ackermann ${ }^{2}$ \\ Emeritus Regter van die Suid-Afrikaanse Grondwetlike Hof
}

\section{Inleiding}

Meneer die Rektor, kollegas, dames en here. My dank aan die Universiteit vir die vriendelike uitnodiging om die gesprek van u forum in te lei, by geleentheid van die herdenking van die selfstandigwording van PUK in 1951. Menswaardigheid as regsbegrip is vir my 'n boeiende onderwerp. Belangriker as my persoonlike voorkeure egter, is die feit dat die konsep menswaardigheid, "human dignity", "Menschenwürde," die murg van ons Grondwet en van ons regstaatlikheid sedert 1994 uitmaak.

\section{Die betekenis van menswaardigheid}

Ek wil eers poog om inhoud aan die begrip menswaardigheid te gee, alvorens ek die vraag aandurf van hoe dit na tien jaar van regstaatlikheid in Suid-Afrika uitsien.

My invalshoek is 'n juridiese, en in besonder 'n staatsregtelike een. Dit is ook 'n sekulêre benadering, omdat ons Grondwet 'n sekulêre konstitusie is. Hierdeur gee ek allermins te kenne dat die teologie van menswaardigheid nie van groot belang is nie; tewens, ekself het groot baat gevind, intellektueel en andersins, by die werk van, byvoorbeeld Jürgen Moltmann ${ }^{3}$ en Duncan Forrester, ${ }^{4}$ wat menswaardigheid - en trouens al die fundamentele menseregte - aan die "imago

1 Inleidende toespraak gelewer by Noordwes-Universiteit (Potchefstroom) op 16 Maart 2004.

2 SC BA LLB (Stellenbosch), MA (Oxford), LLD hc (Stellenbosch), Ere-Genoot, Worcester College, Oxford. Emeritus Regter van die Suid-Afrikaanse Grondwetlike Hof.

3 Moltmann On Human Dignity.

4 Forrester On Human Worth. 
Dei" begrip ontleen. ${ }^{5}$ Ek meen ook dat teologie, en die kerke waaruit dit beoefen word, 'n belangrike rol kan speel by die vestiging van 'n kultuur van menswaardigheid in ons land. My benadering is sekulêr omdat die Grondwet dit vereis en omdat ek my nie as teoloog wil voorhou nie.

Die beginsel en beskerming van menswaardigheid word tans bedreig deur 'n beroep op kulturele relativisme. Die voorrede tot die Universele Menseregteverklaring van 1948 het die inherente menswaardigheid ("inherent dignity") van alle lede van die menslike familie uitgesonder as van die waardes en menseregte wat die grondslag vorm van vryheid, geregtigheid en vrede in die wêreld. Die Verklaring waarsku tereg dat die minagtende miskenning van hierdie waardes aanleiding gegee het tot barbaarse optrede wat die mensdom se gewete geskok het ("resulted in barbarous acts which have outraged the conscience of mankind") en dat hierdie waardes regstaatlik beskerm moet word om te voorkom dat onderdane verplig word, as laaste uitweg, om in opstand te kom teen tirannie en onderdrukking. Dit is hierdie beroep op regstaatlike beskerming wat sommige beskou as die belangrikste beginsel van die Universele Verklaring van Menseregte. Herhaalde mensemoord en menseslagting is seker van die grootste skandvlekke op die mensdom se aanspraak op beskawingsvordering. Kulturele relativisme ten aansien van fundamentele menseregte is nie 'n luukse wat die mensdom kan bekostig nie. Die uitdaging van die een-en-twintigste eeu is om menswaardigheid as onskendbare en universele "Grundnorm" te vestig.

Wat is dit aan menswees wat onderliggend is aan die norm van menswaardigheid? As uitgangspunt aanvaar ek die omskrywing van Prof Günter Dürig in die vyftigerjare, wat in Duitsland as die klassieke definisie beskou word:

Jeder Mensch ist Mensch kraft seines Geistes, der ihn abhebt von der unpersönlichen Natur und ihn aus eigener Entscheidung dazu befähigt, seiner

5 Moltmann On Human Dignity 23: "By fundamental human rights we mean those rights and duties which belong essentially to what it means to be truly human, because without their being fully acknowledged and exercised human beings cannot fulfil their original destiny of having been created in the image of God." 
bewußt zu werden, sich selbst zu bestimmen und sich und die Umwelt zu gestalten. ${ }^{6}$

Nou aansluitend hierby is die siening van Prof Louis Henkin dat:

On the highest level, dignity is a quality of worth or excellence, and when used in the compound term 'human dignity,' it suggests all that for Kant is inherent in the human 'personhood' of every human being.

In hierdie konteks sou ek graag die volgende vier tersaaklike kategoriese imperatiewe van Kant uitlig:

- Eerstens: Tree so op dat jy menslikheid, hetsy in jou eie persoon of in die persoon van 'n ander, altyd ook as 'n doel opsigself gebruik, en nooit bloot as 'n middel (tot 'n doel) nie. ${ }^{8}$

- Tweedens: In die koninkryk van doeleindes het elkeen of 'n prys of 'n waardigheid. Wat 'n prys het kan altyd deur iets anders as sy ekwivalent vervang word; aan die ander kant, dit wat bo alle prys verhewe is en dus geen ekwivalent het nie, het 'n waardigheid ... dit wat die voorwaarde daarstel, slegs waaronder iets 'n doel op sigself is, het nie bloot 'n relatiewe waarde nie, naamlik 'n prys, maar 'n innerlike waarde, dit is, waardigheid". 9

- Derdens: 'n Mens, beskou as 'n persona, dit is, as die subjek van etiese praktiese rede, is bo alle prys verhewe; want as 'n persoon (homo noumenon) word sy nie getakseer bloot as 'n middel tot die doeleindes van ander of selfs tot haar eie doeleindes nie, maar as 'n

6 "Alle mense is menslik vanweë hulle intellektuele vermoë, ("kraft seine Geistes"), wat hulle onderskei van die onpersoonlikheid van die natuur, en hulle in staat stel om hulle eie oordeel uit te oefen, om selfbewussyn te besit, om selfbeskikking uit te oefen en om gestalte aan hulself en die natuur te gee" en "All humans are human by virtue of their intellectual capacity ("kraft seine Geistes") which serves to separate them from the impersonality of nature and enables them to exercise their own judgment, to have self-awareness, to exercise self-determination and to shape themselves and nature" (beide die Afrikaanse en die Engelse vertalings is my eie), Dürig 1956 AÖR 117.

$7 \quad$ Henkin Human Dignity and Human Rights 13.

8 "So act that you use humanity, whether in your own person or in the person of any other, always at the same time as an end, never merely as a means." Kant "Metaphysics of Morals" 429 vertaal deur Gregor en Wood Practical Philosophy 80.

9 "In the kingdom of ends everything has either a price or a dignity. What has a price can be replaced by something else as its equivalent; what on the other hand is raised above all price and therefore admits of no equivalent has a dignity... that which constitutes the condition under which alone something can be an end in itself has not merely a relative worth, that is a price, but an inner worth, that is, dignity." Kant "Metaphysics of Morals" 434-435; Gregor en Wood Practical Philosophy 84. 
doel op sigself, naamlik, sy besit 'n waardigheid ('n absolute innerlike waarde) waarmee sy respek vir haarself afdwing van alle ander rasionele wesens in die wêreld. Sy kan haarself meet teen elke ander wese van die aard, en haarself na waarde skat op 'n grondslag van gelykheid met hulle. ${ }^{10}$

- Vierdens: As doel op sy eie is dit die mens beskore om wetgewend op te tree op die gebied van doeleindes, vry van die wette van die natuur en gehoorsaam slegs aan die wat hy self uitvaardig. Gevolglik kan sy stelreëls deel uitmaak van universele wetgewing waaraan hy self gebonde is. Niks kan waarde hê buite dit wat die reg daarvoor bepaal nie. Maar die wetgewing self, wat alle waarde bepaal, moet om hierdie rede 'n waardigheid hê, dit wil sê, 'n onvoorwaardelike, onvergelykbare waarde; en alleen die woord respek verskaf 'n toepaslike uitdrukking vir die waardering wat die rasionele mens daarvoor moet hê. Outonomie is gevolglik die grondslag van die waardigheid van die menslike natuur en van iedere rasionele skepsel. ${ }^{11}$

Bekende Angelsaksiese regsfilosowe onderskryf 'n soortgelyke benadering. Volgens Ronald Dworkin, wat deels vir John Rawls aanhaal, is die gelyke respek wat aan alle mense toekom "'owed to human beings as moral persons, and follows from the moral personality that distinguishes humans from animals."12 Rawls sien "moral personality and not the capacity for

10 "[A] human being regarded as a persona, that is, as the subject of a morally practical reason, is exalted above any price; for as a person (homo noumenon) he is not to be valued merely as a means to the ends of others or even to his own ends, but as an end in itself, that is, he possesses a dignity (an absolute inner worth) by which he exacts respect for himself from all other rational beings in the world. He can measure himself with every other being of this kind and value himself on a footing of equality with them." Kant "Metaphysics of Morals" 435; Gregor en Wood Practical Philosophy 557. Sien ook "On the Common Saying: That Might be Right in Theory, but it is of no use in Practice" in Gregor en Wood Practical Philosophy 293.

11 "[Because the rational being is] an end in itself and, for that very reason, as lawgiving in the kingdom of ends - [he] is as free with respect to all laws of nature, obeying only those which he himself gives and in accordance with which his maxims can belong to a giving of universal law (to which at the same time he subjects himself). For nothing can have a worth other than that which the law determines for it. But the lawgiving itself, which determines all worth, must for that reason have a dignity, that is, an unconditional, incomparable worth; and the word respect alone provides a becoming expression for the estimate of it that a rational human being must give. Autonomy is therefore the ground of the dignity of human nature and of every rational creature." Kant "Metaphysics of Morals" 436; Gregor en Wood Practical Philosophy 85. Op oorstemmende wyse beklemtoon Isaiah Berlin dat "[I] wish to determine myself, and not be directed by others, no matter how wise and benevolent; my conduct derives an irreplaceable value from the sole fact that it is my own, and not imposed upon me" in die inleiding van Berlin Essays on Liberty xliii

12 Dworkin Taking Rights Seriously 181. 
pleasure and pain as the fundamental aspect of the self." ${ }^{13}$ In die konteks van regstaatlikheid is menswaardigheid dus die erkenning, respek en beskerming wat aan alle mense toekom, beide van die kant van die staat en ook van alle ander onderdane, van en vanweë die mens se unieke eienskappe van selfbewustheid, outonomie en onskatbare en onvergelykbare waarde. Mense is op die minste daarop geregtig om as morele subjekte behandel te word, en nie as blote objekte nie; as subjekte met absolute en inherente waarde en derhalwe ook as morele subjekte met gelyke waarde.

\section{Die regspatologie van apartheid}

Dit is ongewens, indien nie onmoontlik nie, om menswaardigheid in Suid-Afrika ná 1994 te beoordeel, sonder om 'n blik, hoe vlugtig ookal, te gee van die miskenning van menswaardigheid wat ons huidige regstaatlikheid voorafgegaan het. Ek beoog nie maar nog 'n masochistiese selfgeseling nie. Baie konstitusies, maar veral ons Konstitusie en die van Duitsland, is reaktief van aard. Hulle behoorlike betragting en uitleg vereis 'n ontleding - hoe vlugtig ookal - van die mistastings waarteen die konstitusie in reaksie gekom het. Die juridiese kern van apartheid-patologie was, na my oordeel, die uitgebreide en volgehoue poging om die reg op self-identifikasie en self-beskikking van die oorgrote meerderheid van Suid-Afrikaners te ontneem. Dit het ook tot 'n sekere mate - en terloops - die reg op self-identifikasie van blankes ontneem, maar omdat dit in meeste gevalle tot materiële voordeel van die blankes gely het, was die impak anders, maar kon tog skendend wees. Die apartheidstaat het sy bes gedoen om van swartes te ontneem van dit wat ten grondslag van menswees lê, naamlik die reg om 'n mens self te verstaan, of ten minste 'n mens self deur mens se eie vermoëns te definieer en om vrylik as morele agent ooreenkomstig sodanige begrip en self-identifikasie op te tree. Swartes is as 'n middel tot 'n doel gebruik en baie selde as 'n doel op sigself, en op 'n manier wat tot die inversie van feitlik al die reedsvermelde Kantiaanse imperatiewe gelei het. Hierdie inversie het gelei tot 'n soortgelyke fundamentele ontneming van vryheid en 'n oorweldigende miskenning van gelykheid. 


\section{Menswaardigheid na tien jaar van regstaatlikheid.}

Op die gebied van menswaardigheid het tien jaar van regstaatlikheid gepoog om hierdie inversie om te keer ten voordele van almal.

Die 1996 Grondwet ${ }^{14}$ bepaal uitdruklik dat menswaardigheid, as substantiewe waarde, tesame met die bereiking van gelykheid en die uitbou van menseregte en vryhede, een van die hoekstene van die Suid-Afrikaanse staat is. ${ }^{15}$ Menswaardigheid geniet ook, onder die Konstitusie, die hoogste beskerming teen aftakelende wysiging. ${ }^{16}$ Hoewel menswaardigheid die oorkoepelende reg is, waaraan die regte op vryheid (outonomie) en gelykheid (gelykwaardigheid) ontleen is, word laasgenoemde afgeleide regte later afsonderlik in die Grondwet behandel, asook menswaardigheid in enger sin.

In die Handves van Regte, vervat in Hoofstuk 2 van die Grondwet, ${ }^{17}$ word menswaardigheid in artikel 10 nie alleen tot fundamentele reg verklaar nie, wat as sodanig gerespekteer en beskerm moet word, maar word dit ter aanvang verklaar dat elkeen alreeds "ingebore waardigheid" besit. Menswaardigheid is dus ' $n$ konstitusionele kategoriese imperatief.

Dit word wêreldwyd erken dat selfs fundamentele konstitusionele regte nie absoluut is nie, maar dat hulle in gepaste omstandighede deur die staat ingeperk kan word ten einde soortgelyke regte van ander, of die algemene staatsbelang, te beskerm. In artikel 36(1) maak ons Grondwet ook hiervoor voorsiening, maar onderwerp sodanige inkorting aan streng voorvereistes. ${ }^{18}$ Een van die drie stelle vereistes is dat enige beperking van 'n reg "redelik en regverdigbaar" moet wees "in 'n oop en demokratiese samelewing gebaseer op

14 Tensy anders vermeld is alle verwysings na die Grondwet van die Republiek van Suid-Afrika 1996.

15 A $1(\mathrm{a})$.

16 A 74(1) bepaal dat a 1, en a 74(1) self, slegs gewysig kan word deur 'n wetsontwerp wat aangeneem word deur - "(a) die Nasionale Vergadering, met 'n ondersteunende stem van minstens 75 persent van sy lede; en (b) die Nasionale Raad van Provinsies, met 'n ondersteunende stem van ten minste ses provinsies."

17 A 7 tot 39.

18 A 36(1) bepaal soos volg: "Die regte in die Handves van Regte kan slegs kragtens 'n algemeen geldende regsvoorskrif beperk word in die mate waarin die beperking redelik en regverdigbaar is in 'n oop en demokratiese samelewing gebaseer op menswaardigheid, gelykheid en vryheid, met inagneming van alle tersaaklike faktore, met inbegrip van- (a) die aard van die reg; (b) die belangrikheid van die doel van die beperking; (c) die aard en omvang van die beperking; (d) die verband tussen die beperking en die doel daarvan; (e) 'n minder beperkende wyse om die doel te bereik." 
menswaardigheid, gelykheid en vryheid." Respek vir menswaardigheid speel dus hier ook 'n sleutelrol.

Maar die bepalings van ons Handves van Regte werk nie slegs (sogenaamd) vertikaal nie, dit wil sê dit beskerm die individu nie slegs teen ongrondwetlike optrede van die owerheid nie, maar dit werk ook (sogenaamd) horisontaal, dit wil sê die bepalings van die handves vind ook toepassing in die regsverhoudings tussen onderdane onderling. ${ }^{19}$ By sodanige horisontale toepassing

- Moet 'n hof, ten einde gevolg te gee aan 'n reg in die Handves, die gemenereg toepas, of indien nodig ontwikkel, in die mate waarin wetgewing nie aan daardie reg gevolg gee nie; en

- Kan 'n hof reëls van die gemenereg ontwikkel om die reg te beperk, mits die beperking in ooreenstemming met artikel 36(1) is. ${ }^{20}$

Gevolglik is die reg op menswaardigheid nie beperk tot staat/onderdaan regverhoudings nie, maar is ook van toepassing op regsverhoudinge tussen onderdane.

Ten slotte verwys ek, in die konteks van uitdruklike grondwetlike bepalings, na die rol wat menswaardigheid speel by 'n hof se vertolkingsfunksie. In die eerste plek moet 'n hof, tribunaal of forum, by die uitleg van die Handves van Regte, die waardes wat 'n oop en demokratiese samelewing gebaseer op menswaardigheid, gelykheid en vryheid ten grondslag lê, bevorder. ${ }^{21}$ Tweedens moet sodanige hof, by die uitleg van enige wetgewing en by die ontwikkeling van die gemenereg, "die gees, strekking en oogmerke van die Handves bevorder". ${ }^{22}$ 'n Regterlike plig word dus op hierdie wyse geskep om op verskeie wyses menswaardigheid te bevorder.

19 A 8(2) bepaal dat "'n Bepaling van die Handves van Regte bind 'n natuurlike of 'n regspersoon indien, en in die mate waarin, dit toepasbaar is met inagneming van die aard van die reg en die aard van enige plig deur die reg opgelê."

20 A 8(3).

21 A 39(1)(a).

22 A 39(2). 


\section{Regspraak oor menswaardigheid}

In die tyd tot my beskikking is dit onmoontlik om 'n sinvolle oorsig te gee van die regspraak oor menswaardigheid. Ek beperk myself dus tot enkele van die Konstitusionele Hof se uitsprake in hierdie verband.

Seker een van die belangrikste dicta van die Grondwetlike Hof, die implikasies waarvan nog nie volledig besef is nie, handel met die wyer normatiewe rol wat die Grondwet en Handves in ons algemene regsontwikkeling moet speel. Ons deliktereg handel onder andere met die verhaal van skadevergoeding deur 'n eiser van 'n verweerder wat die eiser op onregmatige en nalatige wyse skade berokken het. $\mathrm{U}$ sal onthou dat in die Carmichele saak ${ }^{23}$ dit onder andere gegaan het om die vraag of, in ons deliktereg, die Staat regtens aanspreeklik gehou kon word vir ' $n$ versuim wat daartoe aanleiding gegee het dat 'n aangeklaagde op borg vrygelaat is en terwyl hy op vrye voet was vir Me Carmichele verkrag het. Omgesit in regsterminolgie, was die Staat se versuim in die omstandighede onregmatig. In sy Carmichele-uitspraak het die Grondwetlike Hof onder andere die volgende twee belangrike beginsels neergelê:

- Eerstens: Ons Grondwet is nie bloot 'n formele dokument wat slegs die individu teen die ongrondwetlike optrede van die openbare gesag beskerm nie; dit beliggaam ook 'n objektiewe, normatiewe, waardestelsel. Met ander woorde, die Handves beliggaam nie slegs beskermende subjektiewe regte vir die individu nie maar daarbenewens ook 'n objektiewe waardestelsel wat, as 'n grondliggende konstitusionele waarde vir alle gebiede van die reg, as 'n rigtinggewende beginsel en stimulus werk vir die wetgewer, sowel as vir die uitvoerende- en die regsprekende gesag. ${ }^{24}$

- Tweedens: Voor die nuwe konstitusionele bedeling - wat in 1994 begin het - het regsontwikkeling op die gebied van, onder andere, onregmatigheid in die deliktereg, beleidsbesluite en waarde-oordele geverg. Hierdie besluite en waarde-oordele was veronderstel om die wense, dikwels onuitgesproke, en die persepsies, dikwels maar vaagweg ervaar, van die bevolking weer te gee. (Hierdie proses is na my mening ' $n$

23 Carmichele $v$ The Minister of Safety and Security and the Minster of Justice and Constitutional Development 200110 BCLR 995 (CC); 20014 SA 938 (CC).

24 Supra par [54]. 
klassieke regsfiksie wat bloot 'n dekmantel was vir die betrokke hof se eie persepsies en waarde-oordele. In Carmichele is daar egter beslis dat hierdie tipe besluite en oordele, gebaseer op wense en persepsies van die bevolking, vervang moet word, of aangepas en verryk moet word, deur die toepaslike norme van die objektiewe waardestelsel in die Grondwet beliggaam. ${ }^{25}$

Hierkragtens kan die fundamentele norm van menswaardigheid verder uitstraal na alle gebiede van die reg en die samelewing. Gevolglik is daar bevind dat Me Carmichele geregtig was om skade van die Staat te verhaal omdat die Staat onregmatig opgetree het, en dit op nalatige wyse.

In een van die Hof se eerste uitsprake, $S v$ Makwayane $^{26}$, waarin die doodstraf ongrondwetlik verklaar is, het die belang van menswaardigheid in verskeie van die uitsprake sterk na vore getree. In sy beroep op die waarde van ubuntu, wat in die interim Grondwet se slotbepaling voorgekom het, omskryf Regter Langa aspekte van hierdie idee in terme wat sterk aan Kant herinner:

It recognises a person's status as a human being, entitled to unconditional respect, dignity, value and acceptance from members of the community such person happens to be part of. ${ }^{27}$

So ook Regter Mokgoro waar sy pleit vir:

... the need to revive the value of human dignity in South Africa, and in turn redefine and recognise the right to and protection of human dignity as a right concomitant to life itself and inherent in all human beings. ... [L]ife and dignity are like two sides of the same coin. The concept of ubuntu embodies them both. ${ }^{28}$

Regter O'Regan laat haarself ook op treffende wyse soos volg oor menswaardigheid uit:

The importance of dignity as a founding value of the new Constitution cannot be overemphasised. Recognising a right to dignity is an acknowledgment of the intrinsic worth of human beings: human beings are entitled to be treated as worthy of respect and concern. This right is therefore the foundation of many other rights 
that are specifically entrenched. ... Respect for the dignity of all human beings is particularly important in South Africa. For apartheid was a denial of a common humanity. The new Constitution rejects this past and affirms the equal worth of all South Africans. Thus recognition of and protection of human dignity is the touchstone of the new political order and is fundamental to the new Constitution ... 'it is the dignity and importance of the individual which is the essence and cornerstone of democratic government'. ${ }^{29}$

\section{Menswaardigheid en onbillike diskriminasie}

Dit is op die gebied van regsgelykheid en veral die verbod teen onbillike diskriminasie soos in artikel 9 van die Grondwet beliggaam, dat menswaardigheid bestem is om 'n deurslaggewend belangrike rol te speel. In welke omstandighede differensiasie in die behandeling van mense neerkom op onbillike diskriminasie is 'n uitdagende vraag vir juriste wêreldwyd. In sy heel eerste uitspraak oor onbillike diskriminasie, het die Grondwetlike Hof, in Prinsloo v Van der

Linde ${ }^{30}$ menswaardigheid as toetssteen gebruik om vas te stel wanneer diskriminasie onbillik is. Die Hof onderskryf die standpunt dat:

At the heart of the prohibition of unfair discrimination lies a recognition that the purpose of our new constitutional and democratic order is the establishment of a society in which all human beings will be accorded equal dignity and respect regardless of their membership of particular groups. ${ }^{31}$

en dat:

... inherent human dignity is at the heart of individual rights in a free and democratic society. ... Equality ... means nothing if it does not represent a commitment to recognizing each person's equal worth as a human being, regardless of individual differences. ${ }^{32}$

Op die basis hiervan beslis die Hof dat differensiasie op onbillike diskriminasie neerkom wanneer die onderskeid wat getref word die menswaardigheid van die betrokke persoon of 
persone wat inherent gelyke menswaardigheid besit, aantas. ${ }^{33}$ Hierdie benadering is konstant hierna bevestig.

Die Hof se Kantiaanse benadering tot menswaardigheid blyk nog duideliker uit die volgende passasie:

We are emerging from a period of our history during which the humanity of the majority of the inhabitants of this country was denied. They were treated as not having inherent worth; as objects whose identities could be arbitrarily defined by those in power rather than as persons of infinite worth. In short they were denied recognition of their inherent dignity. ${ }^{34}$

Hierdie benadering word deurgaans deur die Hof gevolg, veral in sy uitsprake oor gelykberegting met betrekking tot seksuele georiënteerdheid en VIGS. ${ }^{35}$

Tyd ontbreek om dit verder toe te lig, maar dit is duidelik dat die aantasting van menswaardigheid 'n belangrike rol gaan speel by die uitleg en toepassing van wetgewing en ander maatreëls met betrekking tot regstellende of vergoedende gelykberegting onder artikel 9(3) van die Grondwet, asook vir die bereiking van konstitusionele ewewig wanneer die sogenaamde horisontale werking van die Handves plaasvind ingevolge die bepalings van subartikels 8(2) en (3).

Ten slotte verwys ek na 'n praktiese wenk wat deur die Hof gegee is in die konteks van seksuele oriëntasie. ${ }^{36}$ Dit is maklik om te sê dat almal wat net soos 'ons' is geregtig is op gelykberegting, maar almal vind dit moeiliker om te sê dat diegene, wat op een of ander wyse 'anders' as 'ons' is, dieselfde reg op gelykheid toekom as wat 'ons' geniet. ${ }^{37}$ Die Grondwetlike Hof merk dan soos volg op:

33 Supra par [31].

34 Supra par [31].

35 Sien bv National Coalition for Gay and Lesbian Equality v The Minster of Justice 199812 BCLR 1517 (CC); 19991 SA 6 (CC); National Coalition for Gay and Lesbian Equality v Minster of Home Affairs 20001 BCLR 39 (CC); 20002 SA 1 (CC); Hoffmann v South African Airways 200011 BCLR 1211 (CC); 20011 SA 1 (CC).

36 National Coalition for Gay and Lesbian Equality v The Minster of Justice supra vn 35.

37 Supra par [22], waar die Hof met goedkeuring die volgende opmerking in Vriend v Alberta (1998) 156 DLR (4th) 385 par 69, met goedkeuring aanhaal: "It is easy to say that everyone who is just like 'us' is entitled to equality. Everyone finds it more difficult to say that those who are 'different' from us in some way should have the same equality rights that we enjoy". 
To understand the 'other' one must try, as far as is humanly possible, to place oneself in the position of the 'other'. ${ }^{38}$

Ek wil op hierdie eenvoudige noot afsluit. In die Grondwet en in ons regspraak word menswaardigheid, in diep en uitgebreide Kantiaanse sin, erken en beskerm. Dit is egter slegs die begin, en nie die einde nie, van die erkenning en beskerming van menswaardigheid in ons gemeenskap. Dit is die taak van ons burgerlike samelewing, en by uitstek die van ons opvoedkundige instellings wat, deur hulle dade sowel as deur hul pedagogie, moet bydra tot die verwesenliking van menswaardigheid vir almal in ons land. 


\section{Bibliografie}

Berlin Essays on Liberty

Berlin I Four Essays on Liberty Galaxy book 191 (Oxford University Press London 1969)

Dworkin Taking Rights Seriously Dworkin RM Taking Rights Seriously (Harvard University Press Cambridge 1977)

Dürig 1956 AÖR

Dürig G "Der Grundsatz von der Menschenwürde" 1956 AÖR 81

Forrester On Human Worth

Forrester DB On Human Worth: a Christian Vindication of Equality (SCM Press London 2001).

Henkin Human Dignity and Human Rights

Henkin L Human Dignity and Human Rights (Jerusalem The Israeli Academy of Sciences and Humanities 1995)

Gregor en Wood Practical Philosophy

Gregor MJ en Wood AW (reds) Practical Philosophy The Cambridge edition of the works of Immanuel Kant 1724-1804 (Cambridge University Press Cambridge 1996)

Kant Metaphysics of Morals

Kant I "Groundwork of the Metaphysics of Morals" in Gregor MJ en Wood AW (reds)

Practical Philosophy The Cambridge edition of the works of Immanuel Kant 1724-1804

(Cambridge University Press Cambridge 1996)

Moltmann On Human Dignity

Moltmann J On Human Dignity: Political Theology and Ethics (Vertaling Meeks MD)

(Fortress Press Philadelphia 1984)

Rawls Theory of Justice

Rawls J A Theory of Justice (Belknap of Harvard University Press Cambridge Mass 1971) 


\section{Register van wetgewing}

Grondwet van die Republiek van Suid-Afrika 1996

\section{Register van hofsake}

Carmichele $v$ The Minister of Safety and Security and the Minster of Justice and Constitutional Development 200110 BCLR 995 (CC)

Carmichele $v$ The Minister of Safety and Security and the Minster of Justice and Constitutional Development 20014 SA 938 (CC)

Hoffmann v South African Airways 20011 SA 1 (CC)

Hoffmann v South African Airways 200011 BCLR 1211 (CC)

National Coalition for Gay and Lesbian Equality and Others v Minster of Home Affairs and Others 20001 BCLR 39 (CC)

National Coalition for Gay and Lesbian Equality and Others v Minster of Home Affairs and Others 20002 SA 1 (CC)

National Coalition for Gay and Lesbian Equality and Another v The Minster of Justice and Others 19991 SA 6 (CC)

National Coalition for Gay and Lesbian Equality and Another v The Minster of Justice and Others 199812 BCLR 1517 (CC)

Prinsloo v Van der Linde and Another 19976 BCLR 759 (CC)

Prinsloo v Van der Linde and Another 19973 SA 1012 (CC)

S v Makwayane and Another 19956 BCLR 665 (CC)

S v Makwayane and Another 19953 SA 391 (CC)

Vriend v Alberta (1998) 156 DLR (4th) 385 